\title{
Biological Control of Some Pathogenic Fungi of Marjoram
}

Islam M. H. Rizk, Mohamed M. M. Amaar², Ibrahim A. Ibrahim³ and Abdel-Hameed M. Othman ${ }^{1}$

${ }^{1}$ Department of Environmental Biotechnology, Genetic Engineering and Biotechnology Research Institute, The University of Sadat city, Sadat city, Egypt.

${ }^{2}$ Department of Agricultural Botany, Faculty of Agriculture, Minufiya University, Egypt.

${ }^{3}$ Department of Plant Biotechnology, Genetic Engineering and Biotechnology Research Institute, The University of Sadat city, Egypt.

*Corresponding author; Email address: islam rizk2@yahoo.com

\begin{abstract}
Marjoram is considered the most important medicinal plant, which is cultivated in Egypt and many countries. Fusarium aquaductuum, fusarium dimerum isolate (1), fusarium dimerum isolate (2) and fusarium aquaductuum var medium are isolated from marjoram plant. These pathogens cause witting of plant. Trichoderma hamatum and Bacillus megaterium are used as biocontrol agents. They applied to inhibit the growth of these pathogens in lab experiments and gave good result that increase quality of marjoram.
\end{abstract}

Keywords: Marjoram, Fusarium species, Trichoderma species, Bacillus megaterium.

\section{INTRODUCTION}

Origanum majoranum L. (Lamiaceae) is found all over Asia, Arabian peninsula, Africa, America and Europe (El- Ashmawy et al., 2007). It is much recognized by its common names, such as sweet marjoram and origano (Al-Howiriny et al., 2009; and Christman, 2010). Marjoram was initially used by hippocrates as an antiseptic agent. It is a well-liked home remedy for chest infection, cough, sore throat, rheumatic pain, nervous disorders, cardiovascular diseases, epilepsy, insomnia, skin care, flatulence and stomach disorders (Bremness, 1994; Faleiro et al., 2005; and Yazdanparast and Shahriyary, 2008).
Many of the folklore medicinal claims about marjoram were confirmed in different experimental models (Busatta et al., 2008). Marjoram alcoholic aqueous extracts and essential oil could protect liver and kidney damage, and lead acetate injury (El-Ashmawy et al., 2005; 2007a, b; and Abd El-Ghany and El-Metwally, 2010). The antiproliferative activity of marjoram was confirmed in human lymphoblastic leukemia cell line Jurkat (Papageorgiou et al., 2008; Abdel-Massih et al., 2010).

The essential oil obtained from the flowering heads of marjoram has aromatic smell and contain high percentage of polyphenols and monoterpenes which are established as antioxidants (Novak et al., 
2000). It is worth mentioning that marjoram volatile oil was also found to control oxidative damages induced by ethanol toxicity to brain, liver, and fertility (Aheme et al., 2007; ElAshmawy et al., 2007a, b). Marjoram oil mixed with other substances is used in aromatherapy (Hazzit et al., 2006; Aromatherapy, 2011). Ursolic acid, carnosic acid, and carnosol isolated from marjoram possessed free radical scavenging properties (Chung et al., 2001; Vagi et al., 2005; Miron et al., 2011). Ursolic acid was found to reduce Abetainduced oxidative injury (Heo et al., 2002). Furthermore it also showed inhibitory effect on acetyl cholinesterase in Alzheimer's disease (Chung et al., 2001).

A variety of biological controls are available for use, but further development and effective adoption will require a greater understanding of the complex interactions among plants, people, and the environment. To that end, this article is presented as an advanced survey of the nature and practice of biological control as it is applied to the suppression of plant diseases. This survey will i) describe the various definitions and key mechanisms of biocontrol, ii) explore the relationships between microbial diversity and biological control, iii) describe the current status of research and application of biological controls, and iv) briefly outline future directions that might lead to the development of more diverse and effective biological controls for plant diseases (Pal, K. K. and B. McSpadden Gardener, 2006).

\section{Material and Methods}

Isolation, purification and identification of the causal organisms

Marjoram plants showed different disease symptoms were collected from different governorates i.e, Dakhliya, Gharbiya, Asiuot, Menofiya, and Sharqia. Plant roots were washed thoroughly using running tap water, surface sterilized by immersing into 0.5 $\%$ chlorine solution for 3 minutes, rinsed several times with distilled sterilized water and then dried between two sterilized filter papers. Samples were cut into small pieces using sterilized cutter and plated on potato dextrose agar medium (PDA) in Petri dishes. Plates were incubated at $25^{\circ} \mathrm{C}$ and examined every day for any fungal growth.

Emerged hyphal tips were separately transferred to new PDA plates and single spore culture technique, using streak method, was used for purification of spore forming fungi, Obtained isolates were identified at Micro Analytical Center, Cairo University.

Isolation of antagonistic microorganisms.

Soil samples from the rhizosphere of healthy marjorm plants collected from some governorates such as Menofiya, Gharbiya and Dakahliya were used to isolate the antagonistic microorganisms.

\section{Isolation of the pathogenic fungi:}

\section{Collection of the infected materials}

Infected marjoram plants showing typical symptoms of wilt, root rot and stolon rot diseases were collected from fields at January, 2010. 


\section{Isolation from the roots}

To isolate internal pathogen, the infected roots were washed thoroughly with tap water and immersed in ethanol $70 \%$ for $1 \mathrm{~min}$. for surface sterilization. The roots were cut into small pieces on sterilized filter papers to dry. The root pieces were transferred on potato dextrose agar PDA medium, incubated at $25^{\circ} \mathrm{C} \pm 1$ and examined every day for fungal growth. Hyphal tips of the edges of the grown cultures were cultured on PDA medium.

Some healthy and/or infected roots were cut into small pieces without serialization, cultured on PDA medium and incubated as mentioned above; in order to obtain either pathogenic or biocontrol microorganisms grow on the roots surface and / or the rhizosphere

\section{Media used}

\section{Nutrient Broth Medium:}

Beef extract, $10.0 \mathrm{~g}$; peptone, $10.0 \mathrm{~g} ; \mathrm{NaCl}$, $5.0 \mathrm{~g}$ and distilled water up to $1000 \mathrm{ml}$.

\section{Potato Dextrose Agar (PDA) Medium}

The extract of peeled $200 \mathrm{~g}$ potatoes after boiling for $20 \mathrm{~min}$. in $300 \mathrm{ml}$ distilled water. After boiling the volume was completed to $1000 \mathrm{ml}$.

Dextrose, $20.0 \mathrm{~g}$; Agar,

$20.0 \mathrm{~g}$; Distilled water up to $1000 \mathrm{ml}$

Biocontrol agents used in the experiments

\section{Source of bioagents}

Trichoderma harzianum, Trichoderma hamatum and Gliocladium virens were obtained from Agricultural Botany Dept., Faculty of Agriculture, Menufiya University. The abovementioned three fungi beside an observed bacterial isolate (Bacillus megaterium) had double action; biofertilizer and biocontrol agents.

\section{Assay of antagonism, in vitro}

The antagonistic effects between different benifecial microorganisms and the pathogens were studied. The selected microorganisms were subjected to the test under laboratory conditions to evaluate their antagonistic effect against the pathogens, Petri plates $(9.0 \mathrm{~cm}$ in diameter) each contained $15 \mathrm{ml}$ of PDA medium were used to detect the antagonistic effect between the pathogens and biocontrol agents in dual cultures.

Different plats were inoculated with $0.6 \mathrm{~cm}$ in diameter disc of each tested fungus obtained from the periphery of 5 days old cultures. Each fungus was cultured at one side of the plate and the opposite side was inoculated with other disc of $0.6 \mathrm{~cm}$ in diameter, obtained from 5 days old culture of Trichoderma spp. or with streak of the antagonistic bacteria grown in nutrient glucose agar medium for 48 hours. Three plates were used as replicates for each particular treatment. Plates inoculated with the pathogenic fungus only served as control treatments.

The inoculated plates were incubated at $25^{\circ} \mathrm{C}$. When mycelial growth cover all the medium surface in a dish of control treatment, all plates were then examined and the redial growth of the pathogens were recorded and percentage of reduction in growth were pooled out using the following formula;

$\%$ Reduction $=$-control- treatment $/$ control *100.

Inhibition zones between the pathogenic fungi and biocontrol agents were estimated. 


\section{RESULTS}

The isolated fungi from diseased marjoram plants showed different disease symptoms were sent for identification at Agricultural Botany Dept., Faculty of Agriculture, Menufiya University.

However both Rhizocatinia solani isolates $(A)$ and $(B)$ colonized roots and stem bases of root-rotted plants.

Fusarium oxysporum and Verticillium dahliae associated the roots of wilted plants. Curvularia lunata isolate was regularly observed in the diseased plants showed yellow brownish leaves.
The above five fungal isolates had high isolation frequency and so they were used further in this investigation.

Results present in Table (1) clear that marjoram samples of Siwa and Matrouh had the least number and percentage of the pathogens. Samples from Dakahlyia and Menufiya yielded the highest frequency of isolates. On the other hand; $F$. oxysporum was more frequently observed in all governorates followed by Rhizocotinia solani (A) and Rhizocotinia solani (B) Curvularia lunata showed the lowest frequency of isolation.

Table (1): Frequency of the isolated fungi from diseased marjoram plants obtained from eight governorates of Egypt.

\begin{tabular}{|c|c|c|c|c|c|c|c|c|c|c|c|}
\hline \multirow{2}{*}{ Governorate } & \multicolumn{2}{|c|}{$\begin{array}{c}\text { Rhizoctonia } \\
\text { solani }(A)\end{array}$} & \multicolumn{2}{|c|}{$\begin{array}{c}\text { Verticillium } \\
\text { dahliae }\end{array}$} & \multicolumn{2}{|c|}{$\begin{array}{c}\text { Curvularia } \\
\text { lunata }\end{array}$} & \multicolumn{2}{|c|}{$\begin{array}{c}\text { Fusarium } \\
\text { oxysporum }\end{array}$} & \multicolumn{2}{|c|}{$\begin{array}{c}\text { Rhizoctonia } \\
\text { solani (B) }\end{array}$} & \multirow[t]{2}{*}{ Total } \\
\hline & No. & $\%$ & No. & $\%$ & No. & $\%$ & No. & $\%$ & No. & $\%$ & \\
\hline Minufiya & 6 & $19^{\circ}$ & 5 & $16 \%$ & 3 & $0.9 \%$ & 10 & $32 \%$ & 7 & $22 \%$ & 31 \\
\hline Gharbia & 4 & 18 & 3 & 13 & 3 & $13 \%$ & 7 & & 5 & $22 \%$ & 22 \\
\hline Sharqia & 5 & $17 \%$ & 6 & $21 \%$ & 4 & $14 \%$ & 8 & $28 \%$ & 5 & $17 \%$ & 28 \\
\hline $\mathrm{Dal}$ & 7 & 21 & 7 & & 5 & $15 \%$ & 7 & 2 & 6 & 18 & 32 \\
\hline Bah & 3 & $21 \%$ & 2 & $14 \%$ & 2 & $14 \%$ & 4 & $28 \%$ & 3 & $21 \%$ & 14 \\
\hline Kafr El-Sheikh & 4 & $28 \%$ & 2 & $14 \%$ & 1 & $0.7 \%$ & 4 & $28 \%$ & 3 & $21 \%$ & 14 \\
\hline Marsa Matroh & 3 & $23 \%$ & 2 & $15 \%$ & 2 & $15 \%$ & 4 & $30 \%$ & 2 & $15 \%$ & 13 \\
\hline El-Wadi E & 2 & $2 \%$ & 1 & $1 \%$ & 2 & $2 \%$ & 3 & $3 \%$ & 2 & $20 \%$ & 10 \\
\hline Total & 34 & & 28 & & 22 & & 47 & & 33 & & \\
\hline
\end{tabular}

\section{Isolation of bioagents}

A bacterial isolates were isolates from rhizosphere of healthy marjoram plants. This isolate was identified as Bacillus subtilis11 and used in biocotrol study.

Pathogenicity tests. Under greenhouse and artificial inoculation conditions, the isolated fungi were tested for their pathogenicity to marjoram plants. Results presented in Table (1) and Figure (1\&2) clears that all tested fungi were pathogenic to marjoram. Fusarium oxysporum was the highly pathogenic isolate both after 30 and 60 days of transplanting. The second rate of infection was attributed to Verticillium dahliae and Curvularia lunata.

The highest disease severity was recorded with Fusarium oxysporum and Verticillium dahliae followed by infection of 60 days after planting.

\section{Laboratory experiments}

\section{Assay of antagonism}

The antagonistic relationships between the benificial microorganisms and the pathogenic fungi were studied, in vitro.

\section{Reduction of mycelial growth}


Results shown in Table (3) and

Figures (3-7) indicate that, all tested bioagents significantly reduced the average diameter of growth of the pathogenic fungi as compared with control. Rhizocotinia solani $(A)$ fungus was severely affected by Bacillus subtilis 11 (73\% reduction). Trichoderma harzianum, $T$. hamatum and $G$. virens reduced the growth of the pathogen by 30.23 and $26 \%$ respectively. Bacillus subtilis 11 was also superior against $V$. dahliae (84\% reduction of the growth). This was followed by $G$. virens ( $66 \% \mathrm{R}$ ) and both Trichoderma spp. which nearly showed the same effect.

Table (2):Severity of infection (\%) with different fungal isolates of marjoram (Pathogenicity test).

\begin{tabular}{|c|c|c|c|}
\hline \multirow{2}{*}{ Isolate } & After 30 days from planting & \multicolumn{2}{|c|}{ After 60 days from planting } \\
\hline & & & \\
\hline Rhizoctonia solani $(A)$ & 12.50 & 16.66 & \\
\hline Verticillium dahliae Curvularia lunata & 12.50 & 19.16 & \\
\hline Fusarium oxysporum Rhizoctonia solani (B) & 14.16 & 20.00 & \\
\hline & 21.10 & 30.56 & \\
\hline & 10.26 & 19.16 & \\
\hline Control & 1.50 & 7.16 & 5.20 \\
\hline $\begin{array}{l}\text { L.S.D at } 5 \% \\
\text { L.S.D at } 1 \%\end{array}$ & $\begin{array}{l}6.93 \\
9.30\end{array}$ & $\begin{array}{c}9.83 \\
13.16 \\
\end{array}$ & \\
\hline
\end{tabular}

Figure (1): Pathogenicity test experiment of different isolates (soil infestation) with spearmint plants.
A . Rhizocotinia solani $(A)$;
B. Verticillium dahliae;:
C . Curvularia lunata;
D. Fusarium oxysporum;
E . Rhizocotinia solani (B). 


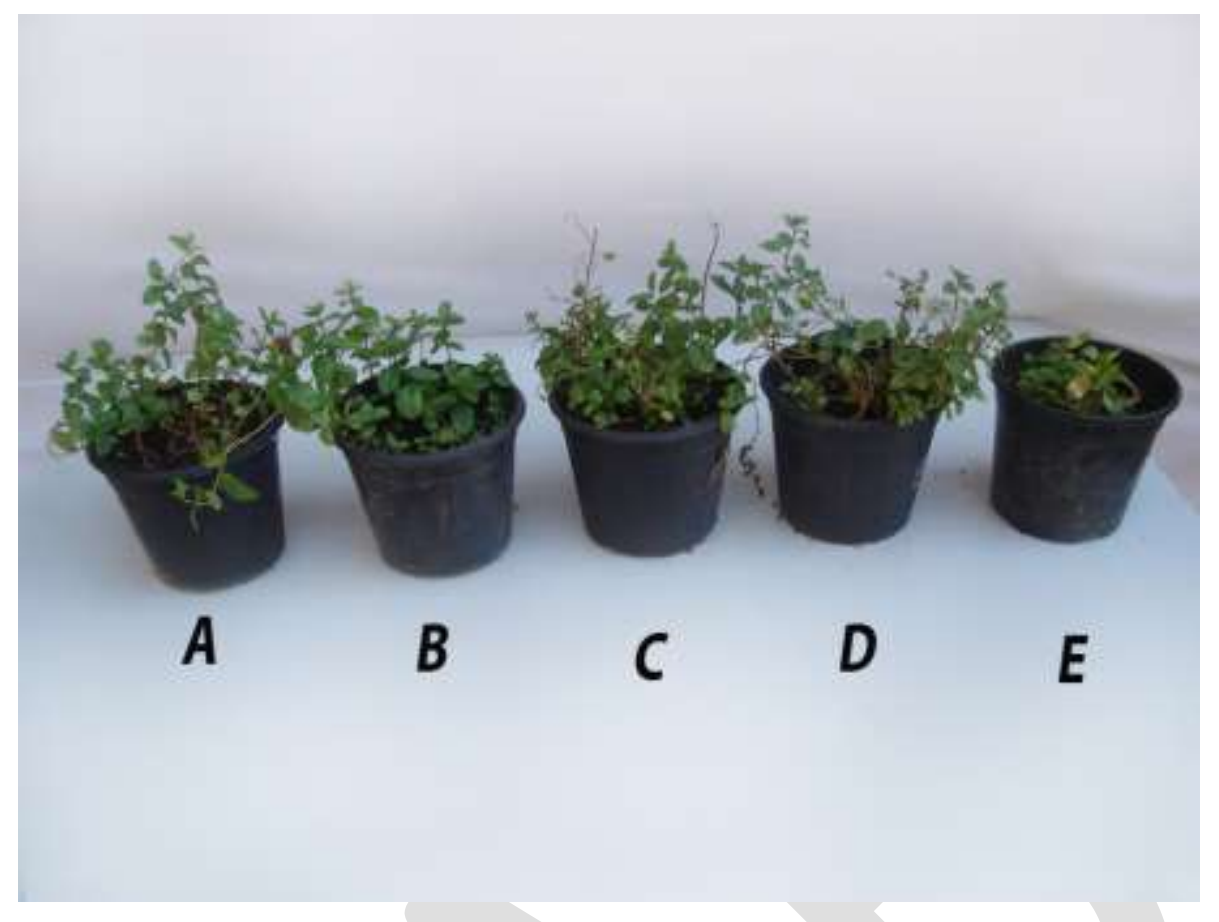

Figure (2): Pathogenicity test experiment of different isolates (soil infestation) with marjoram plants.
A . Rhizocotinia solani $(A)$;
B. Verticillium dahliae.;
C . Curvularia lunata;
D. Fusarium oxysporum.;

E. Rhizocotinia solani (B).

Table (3): Average diameter of growth $(\mathrm{cm})$ and percentage of reduction (\%) of the pathogenic fungi as affected by different biocontrol agents

\begin{tabular}{|c|c|c|c|c|c|c|c|c|}
\hline \multirow[t]{2}{*}{$\begin{array}{l}\text { Biocontrol } \\
\text { agents }\end{array}$} & \multicolumn{2}{|c|}{$\begin{array}{l}\text { Fusarium } \\
\text { asponeductum }\end{array}$} & \multicolumn{2}{|c|}{$\begin{array}{l}\text { Fusarium } \\
\text { dimerum (A) }\end{array}$} & \multicolumn{2}{|c|}{$\begin{array}{l}\text { Fusarium } \\
\text { dimerum(B) }\end{array}$} & \multicolumn{2}{|c|}{$\begin{array}{l}\text { Fusarium } \\
\text { aspoeductumer } \\
\text { var.medium }\end{array}$} \\
\hline & AD (cm) & $\mathbf{R} \%$ & AD (cm) & $\mathbf{R} \%$ & AD (cm) & $\mathbf{R} \%$ & AD (cm) & $\mathbf{R} \%$ \\
\hline Tharsinture & 2.65 & 70 & 3,39 & 62 & 3.05 & 66 & 3.2 & 64 \\
\hline Thamatum & 2.48 & 72 & 2.83 & 68 & 3.6 & 60 & 2.32 & 74 \\
\hline $\begin{array}{l}\text { Bacillus } \\
\text { megaterium }\end{array}$ & 3.72 & 58 & 3.78 & 58 & 4.07 & 54 & 3.95 & 56 \\
\hline Control & 9.00 & & 9.00 & & 9.00 & & 9.00 & \\
\hline \multicolumn{9}{|c|}{ L.S.D between: } \\
\hline \multicolumn{9}{|c|}{ Pathogens (A) } \\
\hline At $5 \%$ & 0.37 & & & & & & & \\
\hline At $1 \%$ & 0.54 & & & & & & & \\
\hline \multicolumn{9}{|c|}{ Biocontiol agents (B) } \\
\hline At $5 \%$ & 0.32 & & & & & & & \\
\hline At $1 \%$ & 0.47 & & & & & & & \\
\hline \multicolumn{9}{|c|}{ Interaction (AB) } \\
\hline At $5 \%$ & 0.64 & & & & & & & \\
\hline At $1 \%$ & 0.93 & & & & & & & \\
\hline
\end{tabular}


Table (4): Average diameter of growth $(\mathrm{cm})$ of the pathogenic fungi as affected by different biocontrol agents.

\begin{tabular}{|c|c|c|c|c|c|c|c|c|c|c|}
\hline \multirow{2}{*}{ Biocontrol agents } & \multicolumn{2}{|c|}{$\begin{array}{c}\text { Rhizoctonia } \\
\text { solani }(A)\end{array}$} & \multicolumn{2}{|c|}{$\begin{array}{c}\text { Verticillium } \\
\text { dahliae }\end{array}$} & \multicolumn{2}{|c|}{$\begin{array}{c}\text { Curvularia } \\
\text { lunata }\end{array}$} & \multicolumn{2}{|c|}{$\begin{array}{c}\text { Fusarium } \\
\text { oxysporum }\end{array}$} & \multicolumn{2}{|c|}{$\begin{array}{c}\text { Rhizoctonia } \\
\text { solani (B) }\end{array}$} \\
\hline & $\overline{A D^{*}}$ & $\mathbf{R}^{\star \star} \%$ & $\overline{A D^{*}}$ & $\mathbf{R}^{\star} \%$ & $\overline{A D^{*}}$ & $\mathbf{R}^{\star} \%$ & $\mathbf{A D}^{*}$ & $\mathbf{R}^{\star} \%$ & $\mathbf{A D}^{*}$ & $\mathbf{R}^{\star \%}$ \\
\hline T. harzianum & 5.67 & 30 & 3.57 & 59 & 2.20 & 73 & 2.02 & 76 & 2.43 & 70 \\
\hline T.hamatum & 6.22 & 23 & 3.63 & 58 & 2.57 & 68 & 3.77 & 56 & 2.23 & 72 \\
\hline Gliocladium virens & 6.00 & 26 & 2.98 & 66 & 2.05 & 75 & 3.97 & 53 & 2.22 & 73 \\
\hline Bacillus subtlus 11 & 2.15 & 73 & 1.42 & 84 & 3.30 & 59 & 3.70 & 57 & 1.82 & 77 \\
\hline Control & 8.13 & - & 8.67 & - & 8.13 & - & 8.50 & - & 8.10 & - \\
\hline L.S.D at $5 \%$ & 0.45 & & 0.63 & & 0.58 & & 1.17 & & 0.78 & \\
\hline L.S.D at $1 \%$ & 0.64 & & 0.90 & & 0.80 & & 1.66 & & 1.08 & \\
\hline
\end{tabular}

${ }^{*} A D$ : Average diameter of growth $(\mathrm{cm})$.

${ }^{*} \mathbf{R}$ : Colony reduction \% compared with control.

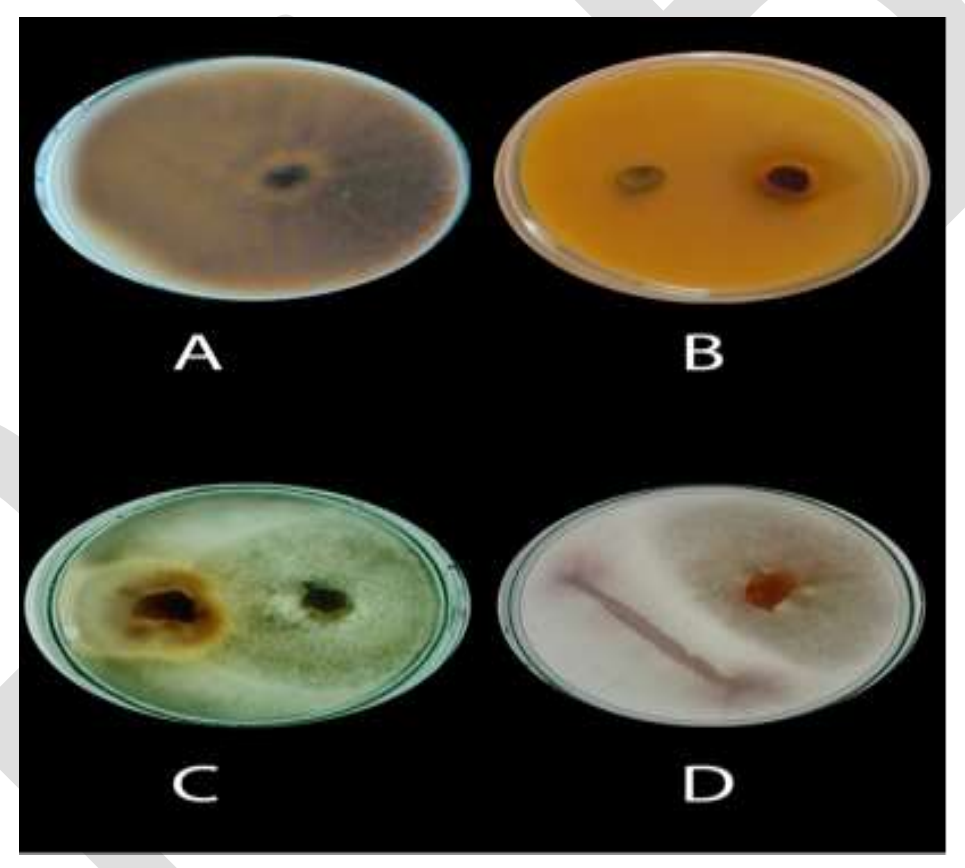

Fig (3): Antagonistic relationships between fusarium aquaeductuum and the tested by control agents.
(A): Control;
(B): Trichoderma harzianum;

(C): Trichoderm hamatum;

(D) Bacillus megateruam

Gliocladium virens and T. harzianum were more effective against Curvularia lunata. However, T. harzianum had more efficacy ( $76 \%$ reduction), than the other three bioagents (53-57\% reduction); when tested against $F$. oxysporum. Rhizoctonia solani $(B)$ was very sensitive to all the bioagents where they reduced its growth from $70 \%$ ( $T$. hamatum) to $77 \%$ (B. subtilis 11$)$. 


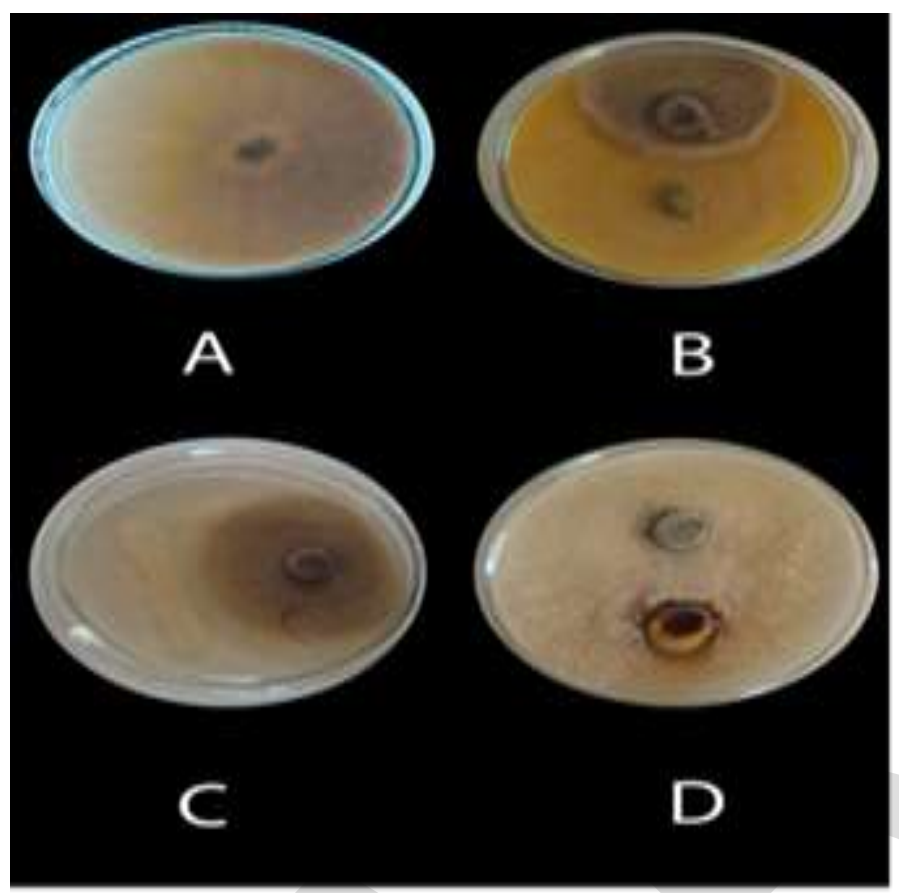

Fig. (4): Antagonistic relationships between fusarium dimerum (A) and the tested by control agents.
(A): Control;
(B): Trichoderma harzianum;
(C): Trichoderm hamatum;
(D) Bacillus megateruam.

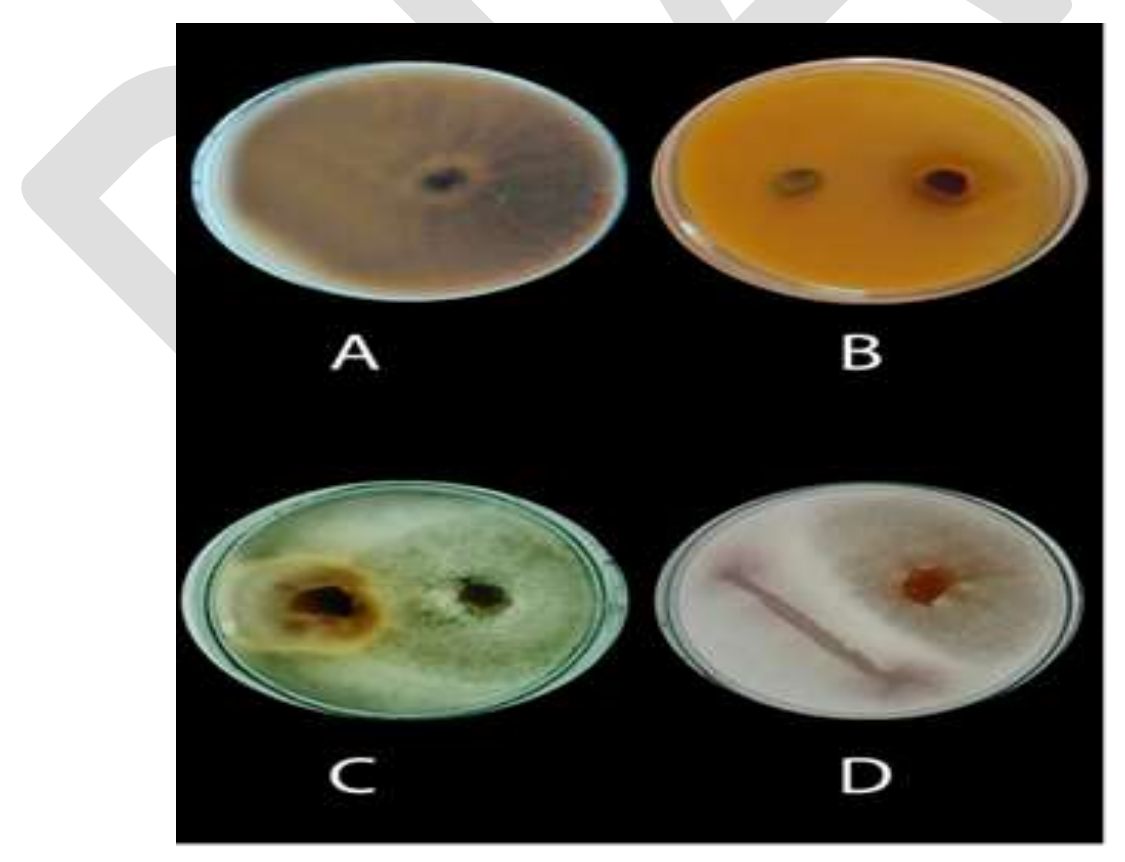

Fig. (5): Antagonistic relationships between fusarium dimerum $B$ and the tested biocontrol agents.
(A): Control;
(B): Trichoderma harzianum;
(C): Trichoderm hamatum
(D) Bacillus megaterium. 


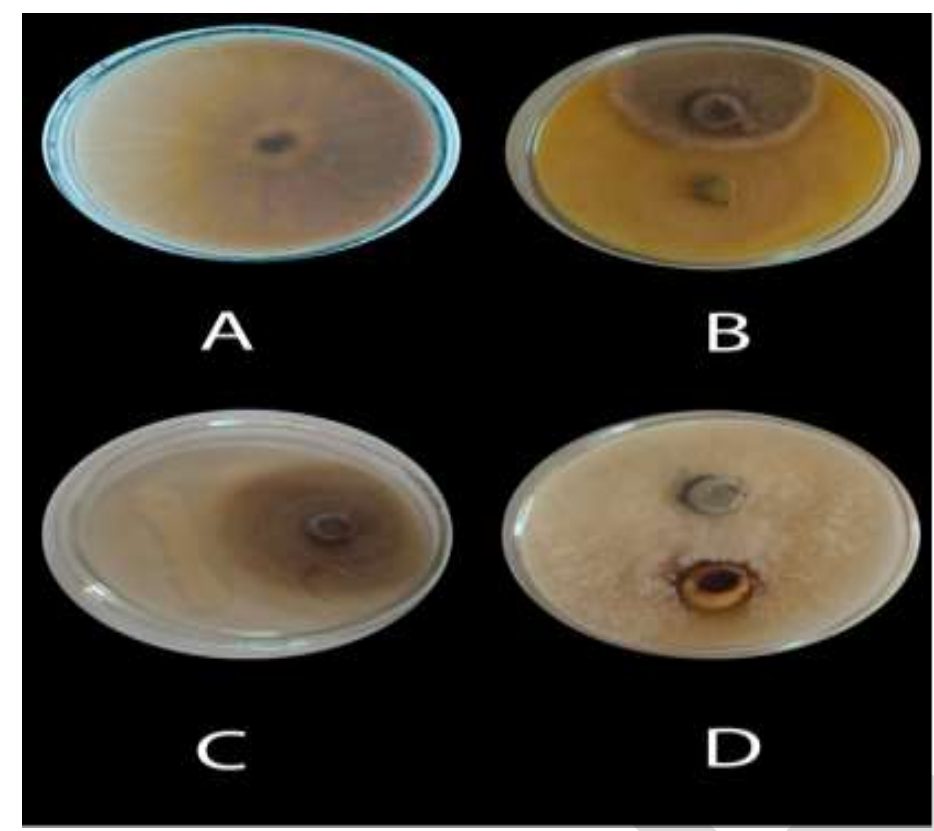

Fig. (6): Antagonistic relationships between Fusarium var.medium and the tested by control agents;

(A): Control;

(C): Trichoderm hamatum
(B): Trichoderma harzianum;

(D) Bacillus megaterium.

\section{DICUSSION}

\section{Marjoram; Origanum marjoranum}

$\boldsymbol{L}$. (Lamiaceae) originated in Egypt and has different common names, such as sweet marjoram and oregano (Al-Howiring et al., 2009 and chrstman , 2010). It is a well-liked home remedy for chest infection, cough, sore throat, rheumatic pain, nervous disorders, cardiovascular diseases, epilepsy, insomnia , skin care, flatulence and stomach disorderes ( Bremness , 1994 ; Faleiro et al ., 2005 and Yazdan parast and Shahriyary, 2008) .

- Rusults of pathogenicity test experiment proved that Fusarium spp. caused wilt symptoms of marjoram plants.

- Bacillus megaterium associated healthy marjoram roots; was positive isolatetes . However, many authors expressed the beneificial of B.subtlus and B.megaterium in biological control process i.e.,
Hamed,(1999),Zheng and Sinclair,(2000)and Brewer Marin \& Larkin(2005).

- On the other hand; $\boldsymbol{T}$. harzinum and T.hamatum which obtained from Agric, bot, Dept., Fac. Agric., Shebin El-kome and used in this investigation are well known as biocontrol agents (Papavizas, 1985).

In vitro studies demonstrated that all tested biocontrol agents reduced mycelial growth of different tested pathogens. Bacillus megaterium was superior in the growth reduction of $\boldsymbol{F}$.aquaeductuum, F.dirmerum

$(\boldsymbol{A})$, Fusarium dimerum (B) and Fusarium aquaeductuum Var.medium. Trichoderma spp.had the second rank in suppression the growth of Fusarium spp.

- Generally, the biocontrol agents could secrete toxins and antibiotics which reduce pathogens growth as reported by Ammar (2003), Daniel et al., (2005, Grosch 
et al.,(2006),Federico et al.,(2007) and Sunil et al., (2007).

- Inhibition zones were noticed between the tested biocontrol agents and the pathogens; when Petri dishes were full with growth, However; when dual cultures were left for seven days incubation, it was noticed that both Trichoerma spp. Grew over the mycelia of the pathogens. The penetration of $\boldsymbol{T}$. harzium Rifai in to the cell wall of other fungi is attributed to the production of enzymes lead to the breakdown of chitin, a primary component of fungal cell wall as reported by Zeillinger et.al, (1999). However; Lu et al., (2004) and Zhu et al., mentioned that the microparasitic hyphae of Trichderma grew alongside the pathogen mycelia followed by coiling and formation of specialized structure similar to hooks, appressoria and papillae.

\section{REFERENCES}

Ammar, M. M. (2003). Fungi (SecondVolume): Physiology, reproduction and their relation to human and environment. El-dar El-Arabia for press and distribution. Cairo, pp.597.

Besnard, G. and A. Berville, (2002). On chloroplast DNA variations in the olive (Olea europaea L.) complex: comparison of RFLP and PCR polymorphisms. Theor. Appl. Gent., V. 104: 1157.

Blumenthal, M., (1998). The complete German Commission Monographs: therapeutic guide to herbal medicines. Austin: American Botanical Council.

Bove, M., (1996). An encyclopedia of natural healing for children and infants. New Canaan, CT: Keats Publishing. Inc.

Brewer Marin, T. and R. P. Larkin, (2005). Efficacy of several potential biocontrol organisms against

Rhizoctonia solani on potato. Crop Protection, 24(11): 939-950.
Coley- Smith, J. R., C. J. Ridout, C. M. Mitchell and J. M. Lynch, (1991). Control of bottom rot disease of lettuce (Rhizoctonia solani) using preparartions Trichoderma viride, $T$. harzianum or tolclofosmethy. Plant Pathol., 4: 359-366.

Cook, R. J., and K. F. Baker, (1983). The nature and practice of biological control of plant pathogens. American Phytopathol. Soc. St. Paul, MN.

Cotes, A. M., H. Pinzon, Y. Elad, S. Freeman and E. Monte, (2001). Effect of seed priming in the presence of Trichoderma koningii on seed and seedling disease induced in tomato by Rhizoctonia solani and Fusarium oxysporum f. $\mathrm{sp}$. lycopersici. Sevilla, Spain, November 30-December 3, 2000. Bulletin-OLLB-SROP, 24, 3, 259363.

Daniel, P. Roberts, Scott M. Lorke, Susan L. F. Meyer, Jeffery S. Buyer, John H. Bowers, C. Jacyn Baker, Wie Li, Jorge $\mathrm{T}$. de Souza, Jack A. Lewis and 
Soohee Chung, (2005).

Biocontrol agents applied individually and in combination for suppression of soil-borne diseases of cucumber. Crop Protection, 24(2): 141-155.

Douhan, L.I., and D.A. Johnson, (2001). Vegetative compatibility and pathogenicity of Verticillium dahliae from spearmint and peppermint. Plant Disease. 85(3): 297-302.

Elad, Y., (2000). Biological control of foliar pathogens by means of Trichoderma harzianum and potential modes of action. Crop Protection, 19: 709-714.

El-Zayat, M.M., I.S. Elewa, M.A. Ahmed, W.H. Zaky (1994). Mint rust disease, species reaction, chemical control and mint oil content. Annals of Agric. Sci., Ain Shams Univ., Cairo, 39 (1): $397-$ 406.

Fareida, M.E. and A. A. Morsy, (2004). Genetic diversity of eight Acacia species using RAPD-PCR analysis. Egypt. J. Genetic and Cytology, 33(2): 307-319.

Federico, G. Rajo, Maria M. Reynoso, Marcella Ferez, Sofia N. Chulzo and Adriana M. Torris, (2007). Biological control by Trichoderma species of Fusarium solani causing peanut brown root rot under field conditions. Crop Protection, 26(4): 549-555.
Fleming, T., (1998). PDR for herbal medicines. Montvale, $\mathrm{NJ}$ : medical Economics Company, Inc.

Foster, S., (1996). Peppermint; Mentha. American Botantical CouncilBotantical Series 306: 3-8.

Gebhart, C. E., A. Baron, T. Debener, B. Walkameier, M. M. Ganal, S. T. anksely and F. Salamini, (1991). RFLP maps of potato and their alignment with the homologues tomato genome. Theor. Appl. Gent., 83: 49-57.

Green, Jr.R.J. and C.B. Skotland (1993). Diseasesof mint (Mentha piperita L., M. cardiaca Baker, M. spicata $L$. and $M$. arvensis

L.). Common Names of Plant Diseases. The American Phytopathological Society. Plant Pathology online.

http://www.apsnet.org/online/com mon/names/mint.asp

Grosch Rita, Katja Scherwinski, Jana Lottmann and Gaberiele Berg, (2006). Fungal antagonists of the plant pathogen Rhizoctaonia solani: selection, control efficacy and influence on the indogenous microbial community. Mycological Research, 110(12): 1464-1474.

Hamed, H. A., (1999). Biological controls of basel stem rot and wilt of cucumber caused by Pythium ultimum and Fusarium oxysporum f. sp. cucumeranum. Afr. J. Mycol. and Biotech., 7(1):81-9 